\title{
BURROWING HABITS OF \\ NORTH AMERICAN SOLPUGIDA (ARACHNIDA) ${ }^{12}$
}

\author{
By MarTin H. Muma \\ Citrus Experiment Station \\ Lake Alfred, Florida
}

\section{Introduction}

North American solpugids, with the possible exception of a few small species of Hemerotrecha Banks and Therobates Muma, are nocturnal. During the daylight hours, the animals rest in specially constructed burrows that vary in depth from I to $23 \mathrm{~cm}$. Burrows are also constructed for food digestion, ecdysis, hibernation, and egg deposition. An individual solpugid may, during its lifetime, dig 40 or more burrows.

Despite the extensive digging operations seemingly necessary for their survival, solpugids curiously lack special burrowing structures (Hingston, 1925). Excepting species of Hexisopodidae, this statement seems to be true for all solpugids (Lawrence, 1963). Burrowing, although conducted with extreme vigor and activity, seems to be accomplished inefficiently and laboriously.

The general facies of solpugid burrowing were presented by Hutton (1843), Turner (1916), Hingston (1925), and Fichter (1940). Although these recorded observations indicated a basic similarity in solpugid burrowing activities, differences suggested possible variations in habit between families, genera, and species.

This report presents a systematic comparison of the burrowing habits of North American solpugids.

\section{Acknowledgments}

Special acknowledgments are due the personnel of the American Museum of Natural History's Southwestern Research Station at Portal, Arizona, for the provision of living and research facilities in the collection area. Mr. Vincent A. Roth, Director, and student assistants also collected specimens.

Mrs. Thelma G. Kanavel, technician, and Michael S. Ball, student, made or assisted with many of the observations reported here.

\footnotetext{
${ }^{1}$ Partial report on studies supported by National Science Foundation Grant GBS-496.

${ }^{2}$ Florida Agricultural Experiment Stations Journal Series No. 2482.

Manuscripi received by the editor September 27, 1966.
} 
Mr. Allen G. Selhime, USDA, ARS, ENT, Orlando, Florida, assisted with photography.

\section{Methods}

Field-collected adult females or late instar nymphs were utilized primarily. Observations were made on specimens both in the field and in the laboratory. Both recently captured specimens, and specimens maintained under laboratory conditions for several weeks were observed in the laboratory. Well-fed and starved individuals of each species were observed when possible. Males of several species were also observed.

Burrowing arenas consisted of well-tamped 5 to $15 \mathrm{~cm}$ depths of a two to one mixture of sand and clay in 20.3 by $25.4 \mathrm{~cm}$ battery jars for most of the observations. Sand, clay, and a one to two mixture of sand and clay were used for a few special observations. Burrow depth and "nest" construction studies were conducted in thin-line arenas made by narrowly separating two panes of glass and filling the space with the sand-clay mixture.

Continuous observations of burrowing specimens were made between initiation of digging and disappearance of the solpugid below the soil surface in a plugged burrow. Regular interval, IO or 20 minutes, observations were made until the solpugid appeared at the side or bottom of the arena and constructed a "nest" or until 2 hours had passed. Two hours were considered sufficient for burrow construction with an unobservable "nest." Special observations were made with an infrared viewer in the dark and sporadically with visual light on burrowing arenas maintained in the dark. Most laboratory observations were made at $26.6^{\circ} \mathrm{C}$ and $70 \%$ relative humidity.

Species identifications follow Muma (1951, 1962, and 1963).

\section{General Burrowing Habits}

The burrowing of subterranean North American solpugids is, in general, very similar to that reported for Asian and African species (Hutton, 1843, and Hingston, 1925). The accounts given by Turner (1916) and Fichter (1940) are too brief and generalized for comparison.

\section{Explanation of Plate 17}

Figures 1 to 6. Eremobates durangonus Roewer. 1. Female (life-size) returning to burrow after plowing. 2. Male (life-size) startled from nest beneath stone. 3. Late nymph $(4 X)$ depositing soil at burrow entrance. 4. Nearly completed burrow plug $(4 \times)$. 5. Late nymph $(2 \times)$ in nest beneath cow pie. 6. Second-instar nymph $(5 X)$ biting soil loose. 

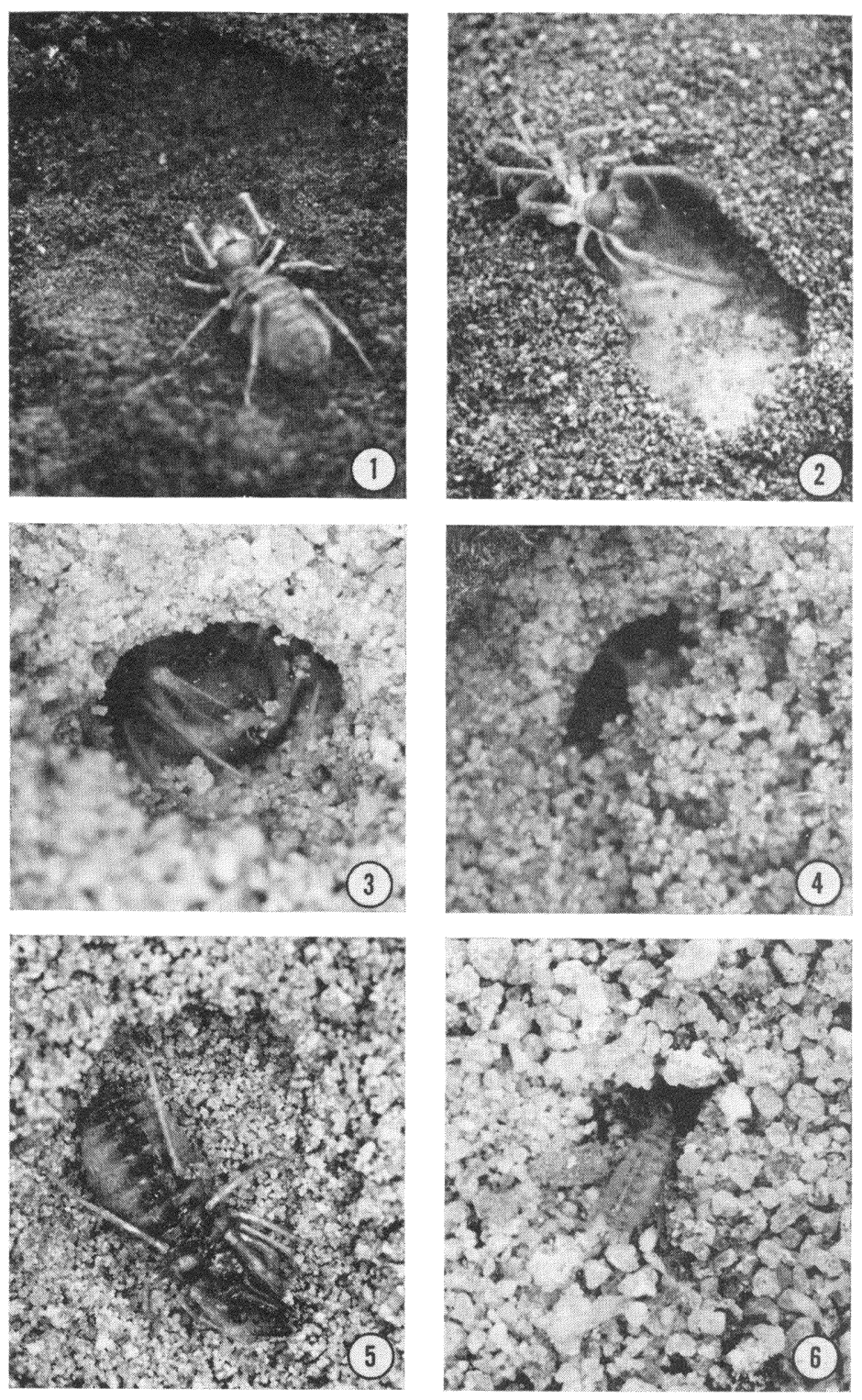

MUMa - Solpugids 
Burrowing consisted of repeated irregular sequences of bitingraking, biting-raking, biting-raking-plowing or raking, raking, raking-plowing. The sequence was continued even after the burrow was plugged and the solpugid's digging was entirely subterranean. The only consistent variation occurred when obstructions such as pebbles, fragments of wood, etc., were encountered. These were bitten free and carried out of the way with the chelicerae. Some species also exhibited two palpal activities: probing, in which the palpi lightly touched unexcavated soil, and tamping, in which the palpi tapped or pushed excavated soil.

The three principal burrowing operations were analyzed. Biting involved both alternate and simultaneous use of the chelicerae. Burrows in hard, firmly packed soil were started by biting while angling, turning, and twisting the propeltidium and chelicerae, or by rotating the entire body around the area being bitten. Raking was accomplished with the laterodorsal row of spines on the tibiae of the second and third legs. The third leg was not used consistently. During raking, the legs were twisted inward and pulled backward quickly either in unison or alternately which hurled the sand and particles of clay backward under the body between the fourth pair of legs. Vigorous raking cast excavated material up to $5 \mathrm{cms}$ behind the solpugid's body. When loose sand and clay accumulated under or just behind a burrowing solpugid, it turned around and plowed the pile out of the way. Plowing involved a lowering of the body to place the chelicerae at or near the base of the pile, the palpi and first legs were flexed at each side of the pile seemingly to prevent lateral scatter, and the pile was pushed as with a bulldozer, or road-grader. Plowing deposited moist excavated material in piles up to $10 \mathrm{~cm}$ from the burrow entrance; dry excavated material was scattered and leveled (Fig. I).

Position reversal in the burrow, not previously reported, was accomplished as follows. The propeltidium was bent to the side or upward and backward over the meso- and metapeltidia and the palpi and legs were folded laterally along the sides of the abdomen. The solpugid then walked backward on the burrow side or ceiling which caused the peltidia and abdominal somites to undergo a backward rolling fold until the animal had completely reversed its position. The solpugid then twisted into an upright position completing position reversal. Position reversals were necessary for plowing, especially when the burrow was one or more body lengths long.

When the burrow was one or more body lengths long, the solpugid plowed only to the entrance (Fig. 3) which closed or plugged the 
entrance (Fig. 4). This plug, by the mechanics of digging, was extended as the burrow was deepened.

Probing usually involved only the palpi; although occasionally the first legs were used. This activity was confined to the unexcavated burrow face. Probing was interpreted as a feeling for large particles but may have assisted in the removal of loosened soil particles.

Tamping was confined to excavated and plowed soil. This activity was interpreted as a reflexive packing of loose soil which assisted in the construction of the burrow plug (Figs. 3 and 4 ).

When the burrow was completed, the solpugid was enclosed in a low-vaulted, oval to round space to which the term "nest" has been applied (Figs. 2 and 5). Vertical and horizontal nest location varied; this is probably governed by inherent factors, but could be an expression of soil type and condition. Nests utilized for ecdysis, egg deposition, and probably hibernation were in longer and deeper burrows than those utilized for daytime resting or digestion.

\section{Specific Burrowing Habits}

A systematic comparison of the burrowing habits of Eremorhax magnus (Hancock), E. pulcher Muma, E. striatus (Putnam), Eremobates durangonus Roewer, E. nodularis Muma, E. palpisetulosus Fichter, Therobates bilobatus Muma, T. n. sp. (arcus group) Ammotrechula peninsulana (Banks), Ammotrechella stimpsoni (Putnam) and Branchia brevis Muma, revealed variations, possibly significant at the species, genus, or family level. In the following subtitled paragraphs, these variations are presented and discussed.

Eremorhax magnus (Hancock). - Burrow depths of I.3, I.9, and $5.4 \mathrm{~cm}$ have been recorded for immatures. Immatures and females were collected from nests beneath cow dung (i.e., cow pies) and rocks. A gravid female was dug out of a burrow $22.9 \mathrm{~cm}$ deep. Burrows were constructed at an abrupt angle to the soil surface, $45^{\circ}$ or more.

This species burrowed extensively in laboratory terraria, completely churning the soil in a single night. The usual biting, raking, and plowing were employed vigorously. Variation was noted in plowing. Chelicerae were slightly separated and held slightly above the base of the soil pile. Moist soil was frequently lifted and carried in the chelicerae, palpi, and first legs. The palpi were used consistently in probing.

Eremorhax pulcher Muma. - This species was not observed in burrows under field conditions.

In the laboratory, immatures utilized biting, raking, and plowing when burrowing but plowed much less frequently than $E$. magnus. 
This species lifted and carried moist soils with the chelicerae and first and second legs but not extensively. This solpugid burrowed more rapidly than E. magnus.

Eremorax striatus (Putnam). - Females have been collected from surface nests under cow pies and rocks.

Under laboratory conditions, males and females constructed only surface nests. Burrowing involved biting, raking, and plowing, with raking predominating. The palpi and first legs swept the soil back to the second legs for raking. Plowing was accomplished with the chelicerae held together.

Eremobates durangonus Roewer. - Burrow depths of $0.6 \mathrm{~cm}$ to I.9 $\mathrm{cm}$ have been recorded for second instar nymphs (Fig. 6). Depths of 3.8 to I $2.7 \mathrm{~cm}$ have been recorded for females. Males (Fig. 2), females, and young (Fig. 5) were collected from surface nests beneath cow pies and stones and were also dug out of burrows 2.5 to $5.8 \mathrm{~cm}$ deep under field conditions. A female and eggs were collected from a $3.8 \mathrm{~cm}$ burrow in the field. Burrows were constructed at a slight angle to the surface, $30^{\circ}$ or less. One immature constructed a burrow at a $45^{\circ}$ angle. Burrows were completed in 30 to 40 minutes by both males and females.

In the laboratory, males, females, and young dug both nests and burrows. The usual biting, raking, and plowing were utilized. This species used the palpi to probe the digging surface while the first legs swept the loosened soil into the raking area. Raking was accomplished vigorously. The chelicerae were held together during plowing and the palpi and first legs used only to prevent lateral scatter of the soil. The palpi were also used regularly in tamping.

Eremobates nodularis Muma. - Burrow depths of 3.8 to $10.2 \mathrm{~cm}$ were recorded for this species. Males and females were collected from nests under rocks; males also from surface nests under cow pies. Burrows were constructed at a $45^{\circ}$ to $90^{\circ}$ angle to the soil surface. Males completed burrows in 15 to 30 minutes, females in 30 to 70 minutes.

In the laboratory, males and females dug both nests and burrows. Biting, raking, and plowing were all utilized. The palpi were used as probes during biting and raking. Palpi and first legs were both used to sweep loosened soil for raking. Vigorous raking seemed to be accomplished mainly with the second legs. Plowing was occasionally used; but most frequently, the load of loosened soil was lifted with the chelicerae, palpi, and first legs, and carried to the dumping area. During this activity, the chelicerae bit into the load but were held together or slightly open. This species frequently braced the third 
and fourth or fourth legs outside of the burrow while biting and raking. The palpi were also used regularly in tamping.

Eremobates palpisetulosus Fichter. - Burrow depths of 2.5 to 5.I $\mathrm{cm}$ have been recorded for males, 7.6 to $10.2 \mathrm{~cm}$ for females. Males and females were collected from burrows and surface nests under cow pies and rocks. Burrows were constructed at an angle of $30^{\circ}$ or less to the surface of the soil. Burrow construction time was not obtained; one male took 60 minutes to burrow out of sight.

In the laboratory, males and females constructed both nests and burrows. Chewing, raking, and plowing were all utilized. Variations were about the same as those of E. durangonus.

A male in a surface nest under a small cow chip burrowed to a depth of $3.8 \mathrm{~cm}$ in 2 hours when heat was reflected onto the surface of the substrate. Twelve hours after heat was removed, the specimen had again constructed a surface nest under cow chip.

Therobates bilobatus Muma. - Two males and one female of this species have been collected from surface nests beneath cow pies. One male was taken from a nest in a cow pie. Burrow angle and burrowing time were not observed.

In the laboratory, males and females constructed both burrows and surface nests. Laboratory-constructed burrows were angled at about $4 \mathrm{O}^{\circ}$ to the substrate surface and were laboriously constructed. Biting, raking, and plowing were all utilized but plowing was minimal. The palpi were not used by the males in plowing; the first and second legs seemed to hold the load.

Therobates n. sp. (arcus group). - A single male of this new species was collected at a night light. In the laboratory, he constructed a burrow $3.8 \mathrm{~cm}$ deep at the base of a twig pushed into the substrate. The angle of the burrow with the substrate surface was not calculated owing to its spiral nature around the twig. The burrow was closed in 95 minutes.

Biting, raking, and plawing were all utilized. The palpi and first legs swept the loosened soil back to the second ligs for raking. Raking was not as vigorous as that exhibited by species of Eremobates. During plowing, the load was encircled by the first and second legs; the palpi were held aloft. Probing and tamping were not recorded.

Ammotrechula peninsulana (Banks).-Burrow depths of 5.1 to $7.6 \mathrm{~cm}$ were recorded for females. Females and immatures were collected from burrows and surface nests. Burrows were constructed at a slight angle, $20^{\circ}$ or less, to the soil surface.

In the laboratory, males, females, and young all constructed bur- 
rows and surface nests. Biting, raking, and plowing were all utilized; but biting and raking were predominant. Soil clods and stones were removed from burrows in chelicerae, sometimes assisted with the palpi, by backing out, not using position reversal. Plowing was accomplished with the chelicerae and first legs; palpi were held to the side and aloft.

Males frequently emerged from burrows during daylight hours in the laboratory.

A female burrowed into and deposited eggs in a section of cornstalk. An immature burrowed into a section of cornstalk and moulted. Both burrows were constructed in the laboratory.

Ammotrechella stimpsoni (Putnam).-A single female and i9 immatures were collected from the Florida Keys in moist termiteinfested and rotten limbs of mangrove, Rhizophora mangle L., and sweet bay, Magnolia virginiana L. During dry periods, no specimens were taken under these conditions. Two immatures were collected from nests under the bark of standing dead pine trees. In the laboratory, females, males, and young all constructed nests and burrows in soil, and nests and burrows in pith, cornstalks, and rotten wood. Subterranean burrowing involved biting, raking, and plowing with variations similar to those exhibited by $A$. peninsulana. Burrows in wood, pith, or cornstalks were constructed by biting and raking with biting predominant. Nests in such media were smaller than those constructed in soil. Young frequently utilized termite galleries or woodboring beetle tunnels rather than burrow in rotten wood.

Branchia brevis Muma.-Three females of this species were collected from surface nests beneath cow pies.

Males and females constructed subterranean burrows in the laboratory. The species did not burrow in pith or cornstalks. Biting, raking, and plowing were all utilized. No unusual variations were noted, but the species is quite small and minor variations could easily have been overlooked.

Males emerged from burrows during daylight hours in the laboratory.

\section{Summary and Discussion}

This comparative study of the burrowing habits of North American solpugids has demonstrated a broad similarity in behavior. All species used the chelicerae to bite at the substrate, pith, wood, or soil; the second and third pair of legs, particularly the second, to rake loosened particles back under the body between the fourth 
pair of legs; the chelicerae sometimes assisted by the palpi and first legs or first legs and second legs to plow excavated materials out of the burrow. During biting, the palpi were used as probes on the face of the excavation. The palpi were also used to tramp excavated material after it was dumped outside of or at the entrance to the burrow.

Variations in substrate, burrow angle, burrowing time, biting, raking, plowing, probing, and tamping seem to indicate the existence of specific, generic, and perhaps familial behavior.

In the family Eremobatidae, three genera and eight species were studied.

Eremorhax magnus (Hancock) and E. pulcher Muma, two morphologically similar short-legged species (Muma, I95 I and I963) burrowed extensively, biting, raking, and plowing vigorously. They differed primarily in the support of soil lifted and carried in the chelicerae. On the other hand, Eremorhax striatus (Putnam), a longlegged species with many Eremobates-like characters (Muma, I95 I) constructed only surface nests principally by raking.

Eremobates durangonus Roewer, E. palpisetulosus Fichter, and $E$. nodularis Muma constructed both nests and burrows, biting, raking, and plowing vigorously. E. durangonus and E. palpisetulosus burrowed at a slight angle, seldom lifting and carrying soil ; whereas, $E$. nodularis burrowed at a $45^{\circ}$ to $90^{\circ}$ angle frequently lifting and carrying soil. The behavioral similarity of $E$. durangonus and $E$. palpisetulosus and the differences exhibited by $E$. nodularis become more striking when it is noted that $E$. durangonus is a species of the pallipes-group and E. nodularis one of the palpisetulosus-group (Muma, I95I). It should also be noted that $E$. nodularis lifted and carried soil in the same manner as Eremorhax magnus and E. pulcher.

Therobates bilobatus Muma and T. n. sp. (arcus group) burrowed slowly and laboriously, primarily biting and raking. Neither species used the palpi in plowing.

In the family Ammotrechidae, three genera and three species were studied.

Ammotrechula peninsulana (Banks) and Ammotrechella stimpsoni (Putnam), two generically different, similar-sized species burrowed in both soil and pith or wood. Both species primarily utilized biting and raking in the construction of subterranean burrows. $A$. stimpsoni regularly burrowed by biting in pith or wood, $A$. peninsulana only once. Furthermore, $A$. peninsulana males emerged from burrows during daylight hours; $A$. stimpsoni males did not. 
Branchia brevis Muma constructed only subterranean burrows and nests by biting, raking, and plowing. The males did, however, emerge from burrows during daylight hours.

Fichter, EDSON

\section{References Cited}

1940. Studies of North American Solpugida, I. The True Identity of Eremobates pallipes (Say), Amer. Mid. Nat., 24 (2): 351-360. Hingston, R. W. G.

1925. Nature at the Desert's Edge, Studies and Observations in the Bagdad Oasis, London, Witherby, Arachnida, pp. 192-261.

Hutron, Thos.

1843. On Galeodes (vorax?), Ann. Mag. Nat. Hist., 75: 1-6.

LAWRENCE, R. F.

1963. The Solifugae of South West Africa, Cimbebasia, 8: 1-28.

Muma, Martin H.

1951. The Arachnid Order Solpugida in the United States, Bull. Amer. Mus. Nat. Hist., 97, (2) : 35-141.

1962. The Arachnid Order Solpugida in the United States, Supplement I, American Museum Novitates No. 2092, pp. 1-44.

1963. Solpugida of the Nevada Test Site, Brigham Young Univ., Sci. Bull. Biol. Ser. 3 (2) : 1-15.

TURNER, C. H.

1916. Notes on the Feeding Behavior and Oviposition of a Captive American False Spider, Jour. Animal Behavior, 6: 160-168. 

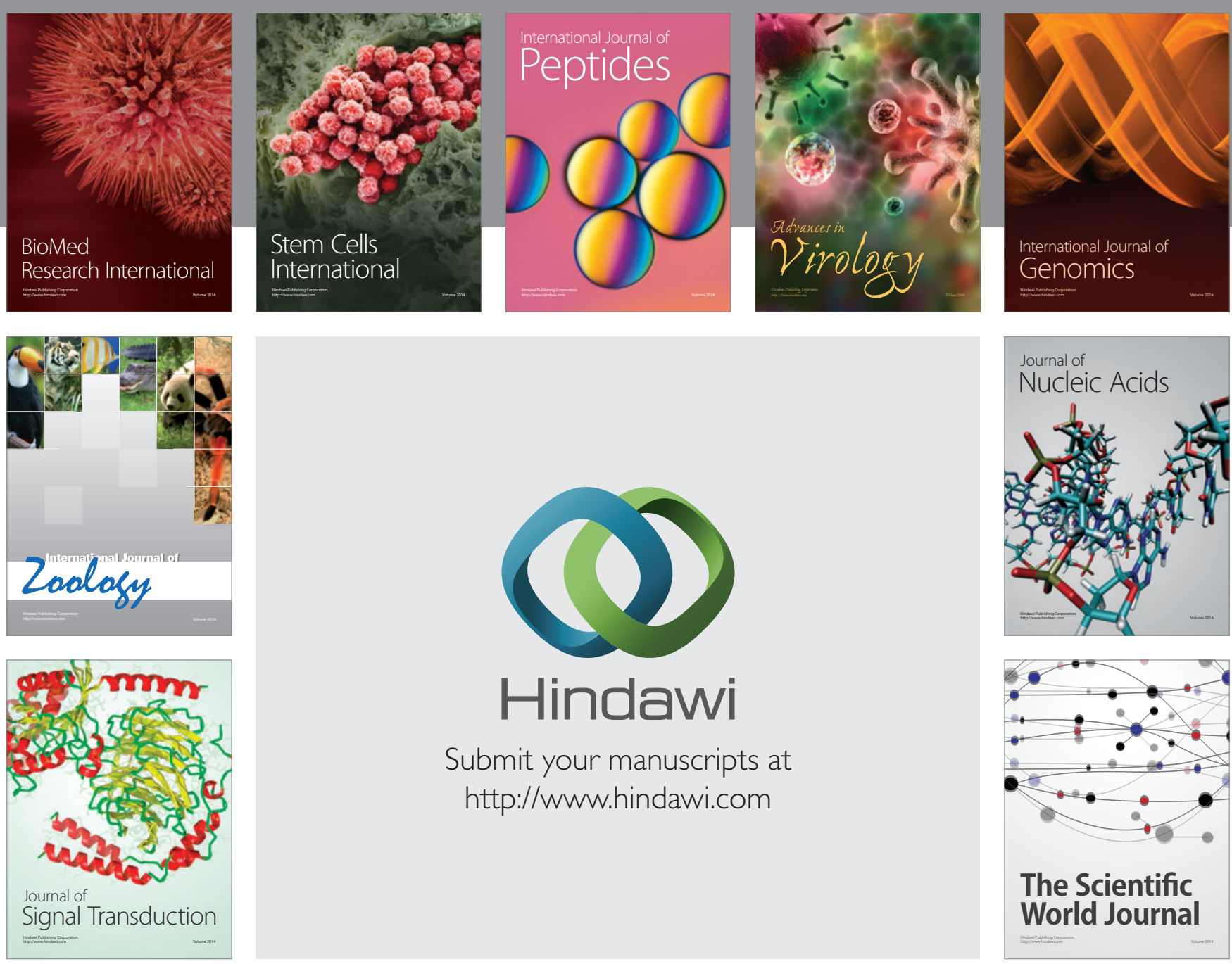

Submit your manuscripts at

http://www.hindawi.com
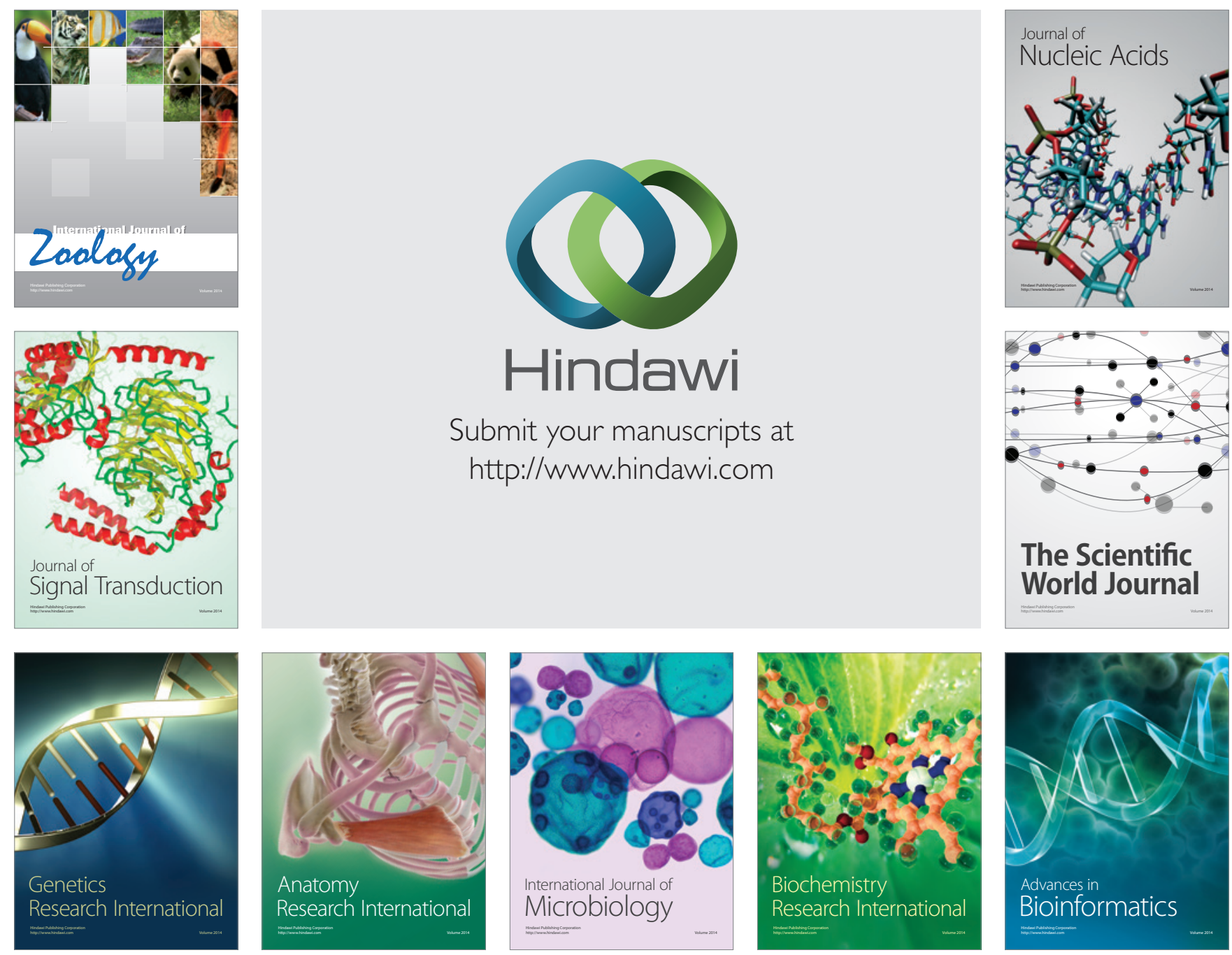

The Scientific World Journal
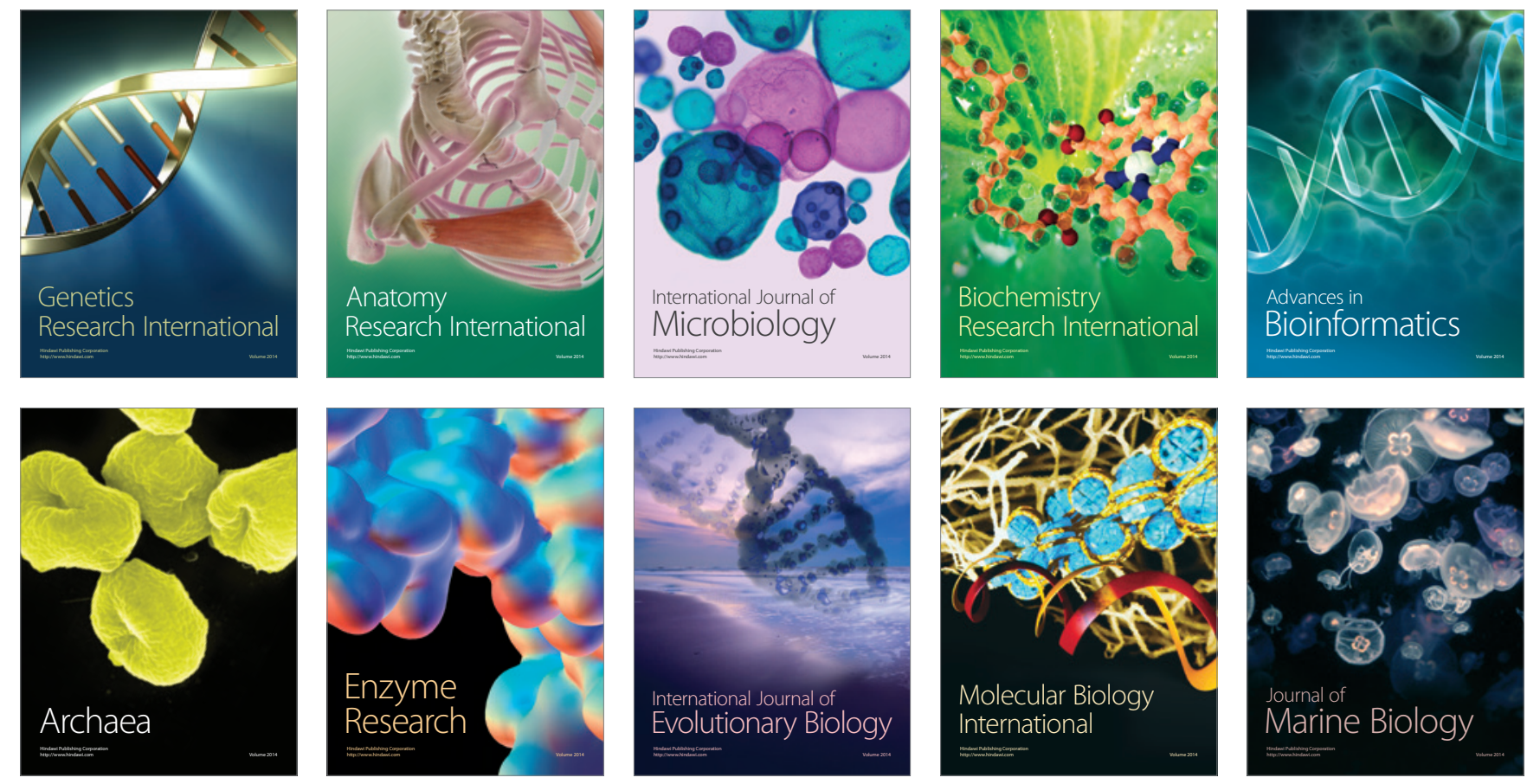